Article

\title{
Impact of Climate Change on Streamflow Hydrology in Headwater Catchments of the Upper Blue Nile Basin, Ethiopia
}

\author{
Abeyou Wale Worqlul 1,*(D), Yihun Taddele Dile ${ }^{2}$, Essayas Kaba Ayana ${ }^{2}$, Jaehak Jeong ${ }^{1}$, \\ Anwar Assefa Adem ${ }^{3}$ (D) and Thomas Gerik ${ }^{1}$ \\ 1 Blackland Research Center, Texas A\&M AgriLife Research, Temple, TX 76502, USA; \\ jjeong@brc.tamus.edu (J.J.); t-gerik@tamu.edu (T.G.) \\ 2 Spatial Sciences Laboratory, Texas A\&M University, College Station, TX 77843, USA; \\ yihundile@tamu.edu (Y.D.T.); essayaskaba@gmail.com (E.K.A.) \\ 3 Faculty of Civil and Water Resource Engineering, Bahir Dar University, Bahir Dar P.O.Box 26, Ethiopia; \\ unnxuss@gmail.com \\ * Correspondence: aworqlul@brc.tamus.edu; Tel.: +1-254-774-6020
}

Received: 5 October 2017; Accepted: 24 January 2018; Published: 29 January 2018

\begin{abstract}
This study assessed the impact of climate change on water availability and variability in two subbasins in the upper Blue Nile basin of Ethiopia. Downscaled future climate data from HadCM3 of A2 (medium-high) and B2 (medium-low) emission scenarios were compared to the observed climate data for a baseline period (1961-1990). The emission scenario representing the baseline period was used to predict future climate and as input to a hydrologic model to estimate the impact of future climate on the streamflow at three future time horizons: 2020-2045, 2045-2070 and 2070-2100. Results suggest that medium-high emission scenario best represents the local rainfall and temperature pattern. With A2 scenario, daily maximum/minimum temperature will increase throughout the future time horizons. The minimum and maximum temperature will increase by $3.6^{\circ} \mathrm{C}$ and $2.4^{\circ} \mathrm{C}$, respectively, towards the end of the 21st century. Consequently, potential evapotranspiration is expected to increase by $7.8 \%$, although trends in annual rainfall do not show statistically meaningful trends between years. A notable seasonality was found in the rainfall pattern, such that dry season rainfall amounts are likely to increase and wet season rainfall to decrease. The hydrological model indicated that the local hydrology of the study watersheds will be significantly influenced by climate change. Overall, at the end of the century, streamflow will increase in both rivers by up to $64 \%$ in dry seasons and decrease by $19 \%$ in wet seasons.
\end{abstract}

Keywords: climate change; HBV; climate projection; Ethiopian highland

\section{Introduction}

Greenhouse gases emissions have significantly increased since the industrial revolution and led to global warming [1]. According to the Intergovernmental Panel on Climate Change (IPCC [2]), the atmospheric concentration of $\mathrm{CO}_{2}$ has increased from $280 \mathrm{ppm}$ in 1750 to $367 \mathrm{ppm}$ in 1999. The concentration increased to over $400 \mathrm{ppm}$ in 2015 and it is expected to reach 463-623 ppm by 2060 and 470-1099 ppm by 2100 [3]. Scientific evidence indicates that increased greenhouse gas emissions will cause an increase in average temperature of the earth by up to $1.4-5.8^{\circ} \mathrm{C}$ by the end of the century [4-6]. Recently, several places across the world have experienced record-breaking meteorological extremes since measurements began $[7,8]$.

Climate change will have a profound impact on the availability and variability of fresh water as the frequency of climatic extremes such as heat waves, drought, and change in rainfall pattern 
increases in response to global warming [9]. The uncertainty of the availability of water resources will affect agricultural production, challenge socio-economic systems, and threaten environmental sustainability by increasing use of non-recyclable resources to feed the growing population. The effect of climate change will be significant particularly in developing countries where their economy is heavily dependent on agricultural production $[10,11]$. The IPCC indicated Africa as one of the most vulnerable continents to climate change and climate variability [10]. Ethiopia is one of the African countries whose economy is largely dependent on agriculture [11-13]. Therefore, the country's economy is subjected to a direct impact of climate change. A large portion of lands in Ethiopia is arid or semi-arid, inhabited by poor and vulnerable communities wholly dependent on rainfall. In addition, poor land management coupled with increasing climate extremes is affecting the livelihoods of these communities. It is therefore important to understand the impact of climate change on water resources to implement appropriate climate change adaptation and mitigation strategies. Expansion of small-scale irrigation is one of the mitigation strategies under consideration where dry season streamflow is reliable [14-16]. However, implementation of such strategies requires a thorough assessment of the impact of climate change on streamflow that is highly sensitive to climate, especially to changes in precipitation, snow regime and evapotranspiration $[17,18]$. Climate change scenarios from either General Circulation Models (GCMs) or simple analog models are frequently used to assess the hydrological impacts of climate change [19-22]. Since the impact of climate change can be significantly variable in different regions, it is important to conduct such study at critical agro-ecological regions to develop and implement adaptation and mitigation strategies.

The objective of this study is to evaluate the impact of climate change on the water resources availability of Beles subbasin in the upper Blue Nile basin using projected climate data and hydrological modeling. The basin is considered as one of the growth corridors in Ethiopia where large-scale development projects such as the Grand Ethiopian Renaissance Dam (GERD) and the Tana-Beles sugar factory are underway.

\section{Data and Methodology}

\subsection{Study Area}

The study area is located in the Beles basin in the western part of the upper Blue Nile basin, Ethiopia. The Beles basin $\left(10^{\circ} 20^{\prime}-12^{\circ} 00^{\prime} \mathrm{N}\right.$ and $\left.35^{\circ} 00^{\prime}-37^{\circ} 00^{\prime} \mathrm{E}\right)$ represents $8.0 \%\left(176,000 \mathrm{~km}^{2}\right)$ of the Blue Nile basin (Figure 1A). The basin is gauged at two locations: one at the outlet of Main Beles and another at the outlet of Gilgel Beles, with catchment areas of $3485 \mathrm{~km}^{2}$ and $742 \mathrm{~km}^{2}$, respectively (Figure 1B). The Gilgel Beles watershed (average altitude of $1735 \mathrm{~m}$ ) is situated at a higher altitude than the Main Beles (average altitude of $1460 \mathrm{~m}$ ). Rainfall in the area is unimodal with a prolonged dry spell from November to May followed by a wet season from June to October. The study area receives $\sim 70-80 \%$ of the total rainfall between June and September.

\subsection{Hydro-Climatic and Spatial Data}

Hydro-climatic data such as climatic and hydrological are required to simulate and calibrate a hydrological model. Meteorological stations located inside the study subbasins do not have continuously recorded daily climatic data for a long period. However, one nearby station (Dangila) has a long period of daily climate data, since 1960, but the other two nearby stations (Chagni, and Pawe) indicated many missing data in the 1970s, 1980s and 1990s. All the climate variables such as rainfall, maximum/minimum temperature, relative humidity, wind speed and daily sunshine hours were available only at Dangila station, while Chagni and Pawe only have rainfall and temperature data. Both subbasins receive a similar amount of rainfall, the average annual rainfall is approximately $1560 \mathrm{~mm}$ with a standard deviation of $165 \mathrm{~mm}$. The Standard Precipitation Index (SPI [23]) was used to understand the rainfall variability throughout the study period. SPI is adopted by the World Meteorological Organization (WMO) to characterize metrological drought. It is a normalized index 
representing the number of standard deviation by which the observed anomaly deviated from the long-term mean. The analysis indicated that, for the study period (1998-2005), 75\% of the time the annual rainfall received by both subbasins is considered as normal rainfall which is within one standard deviation from the mean. The remaining $12.5 \%$ represents moderately wet and dry condition $(12.5 \%)$. The climate data from Dangila station was used to estimate the potential evapotranspiration using Penman-Monteith method [24]. Streamflow is observed twice a day at twelve-hour intervals at the outlets of Main Beles and Gilgel Beles river gauging stations. Despite the continuous effort to collect up to date data, the streamflow data collected were only for the period from 1998 to 2005. The average monthly observed flow (1998-2005) and average spatial rainfall of Main Beles and Gilgel Beles are presented in Figure 2.
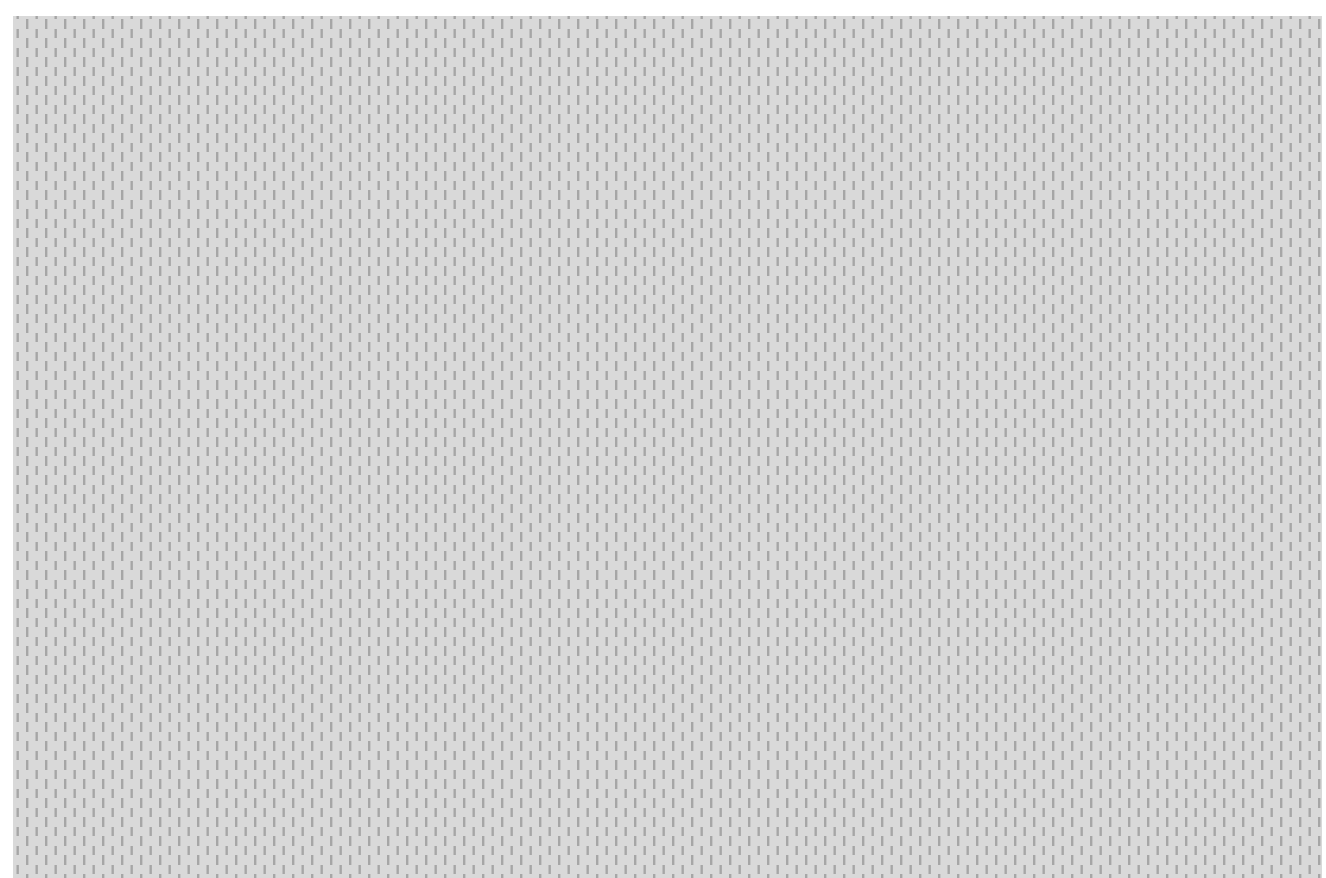

Figure 1. Location of the study area, river network, and rainfall gauging stations: (A) location of the Blue Nile and Beles Basin in East Africa and Ethiopia; and (B) river network of Main and Gilgel Beles and rainfall gauging stations with $30 \mathrm{~m}$ resolution Digital Elevation Model (DEM) as a background.

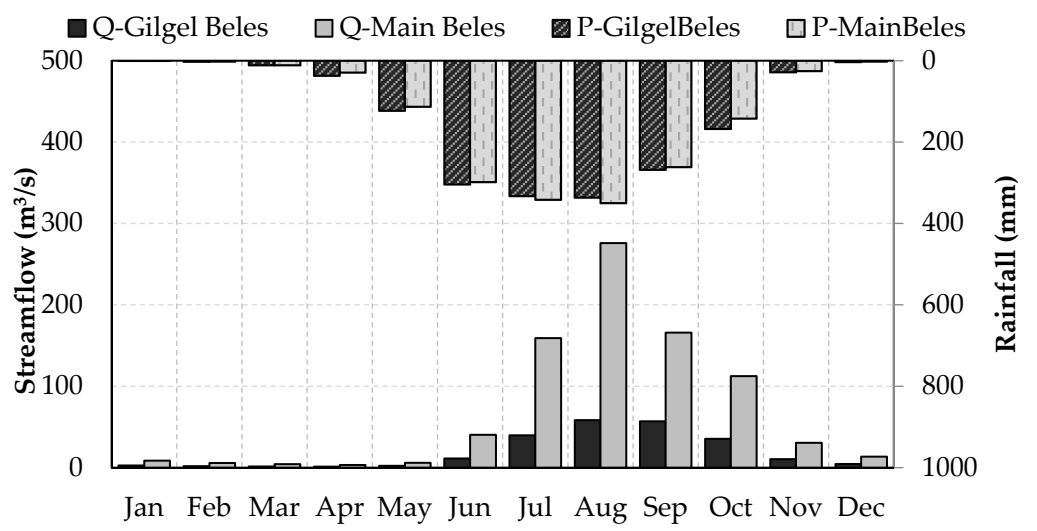

Figure 2. Average monthly streamflow and areal average rainfall of Main Beles and Gilgel Beles for the period 1998-2005.

The 30-m resolution Digital Elevation Model (DEM) from the United States Geological Survey (USGS) was used to delineate the watershed, and generate the drainage pattern and associated 
physiographic attributes. The land use and soil data were obtained from the Ethiopian Ministry of Water and Energy. The land use data indicated that agricultural land accounts for $73 \%$ and $49 \%$ of the Gilgel Beles and Main Beles subbasins, respectively. Grassland is the second major land use type in Gilgel Beles subbasin (26.7\%), while bushland (37\%) is for Main Beles subbasin. The soil for the Gilgel Beles subbasin is dominated by Alisols which contains higher clay content with a low base saturation and susceptible to erosion [25]. The major soil for the Main Beles is Fluvisols (32\% silt and 61\% clay) which is categorized as young soils with a good natural fertility [25].

\subsection{Methods}

The impact of climate change on streamflow was studied in three steps. Initially, a semi-distributed hydrological model called Hydrologiska Byråns Vattenbalansavdelning (HBV [26]) was calibrated to simulate streamflow. The HBV model was selected due to its proven performance in capturing the observed streamflow of several watersheds in the upper Blue Nile basin [19,27-31]. In addition, the model is less input data intensive compared to other distributed hydrological models. The calibrated model was validated with an independent dataset, as described in Section 2.3.2. Thereafter, the General Circulation Model (GCM) data were downscaled using statistical downscaling model (SDSM, [32]). The A2 (medium-high) and B2 (medium-low) emission scenarios were downscaled to represent the future climate at subbasins level. The SDSM downscaled future climate was compared with the observed data for the baseline period. Finally, the downscaled future climate data from the two emission scenarios, which captured the gauged climate data in the baseline period, were used as input to the calibrated and validated HVB model to evaluate the effect of future climate data on the streamflow of Main Beles and Gilgel Beles subbasins.

\subsubsection{Hydrological Model Description}

The HBV model is a semi-distributed conceptual hydrological model [26,33]. In HBV, a watershed is divided into sub-watersheds and further into elevation and land use zones. The model simulates daily runoff from daily rainfall, temperature, long-term average monthly potential evapotranspiration, landscape characteristics and observed runoff data for calibration. The general water balance is described as:

$$
P-E-Q=\frac{d}{d t}[S P+S M+U Z+L Z+\text { lakes }]
$$

where $P$ is the precipitation, $E$ is the evapotranspiration, $Q$ is the runoff, $S P$ is the snowpack, $S M$ is the soil moisture, $U Z$ is the runoff from the upper ground zone, $L Z$ is teh runoff from the lower ground zone, and lakes is the lake volume. All components are estimated as $\mathrm{mm}$ of water.

The model consists of subroutines for precipitation and snow accumulation, soil moisture accounting, response routine, transformation function and simple routing procedure. Precipitation is computed separately for each elevation/vegetation zone within the subbasin [26]. Soil moisture accounting controls the runoff formation. Soil moisture accounting routine is based on three parameters Beta, limit for potential evaporation (LP), and field capacity (FC). Beta controls the contributions to the response function $(\Delta \mathrm{Q} / \Delta \mathrm{P})$ or the increase in soil moisture storage $(1-\Delta \mathrm{Q} / \Delta \mathrm{P})$ from each millimeter of rainfall or snowmelt. LP is a soil moisture value above which evapotranspiration reaches its potential and FC is the maximum soil moisture storage (in $\mathrm{mm}$ ). Response routine transforms the excess water from the soil moisture zone. The response routine consists of upper and the lower linear reservoirs. The upper reservoir is coupled to the soil moisture zone by seepage. When the seepage from the soil moisture routine exceeds the percolation capacity, the upper reservoir starts to fill and at the same time, the water will percolate to the lower reservoir by a percolation parameter (PERC) $[27,28]$. The lower reservoir represents the groundwater that contributes to the baseflow. KHQand K4 are recession coefficients of the upper and lower reservoir, respectively. For the model calibration, the most sensitive model parameters controlling the output variable (flow) were identified from SMHI [34], and include Alfa, Beta, FC, K4, KHQ, LP, and PERC. 


\subsubsection{Model Calibration, Validation, and Performance Evaluation}

A semi-automated approach was applied to calibrate the HBV model calibration process. Initially, minimum and maximum limits of the parameters were set based on a literature and local knowledge of the watershed $[19,28,31]$. The data were split into calibration and validation by split sampling where $70 \%$ of the data were used for calibration and the remaining for validation [35]. After initializing the model, an automatic calibration was performed using a Monte Carlo computation procedure. The model was calibrated for the period 1999-2003 and validated for the period 2004-2005. The model performance was also evaluated annually and over dry (November to May) and wet (June to October) seasons. Percent Bias (PBIAS), Nash-Sutcliffe Efficiency (NSE) and Coefficient of Determination (R-square) were used to evaluate the model performance.

Wilby and Harris [36] and Chen et al. [37] ranked Global Circulation Models (GCMs) and downscaling methods as the greatest uncertainty in the climate change impact studies. Brigode et al. [37] also indicated the dependency of the optimal model parameter sets on the climate characteristics of the calibration period, which is different from the projection period. Brigode et al. [37] further proposed methods to reduce the uncertainty associated with the optimal model parameters, which includes testing the model parameters by the two contrasted periods such as dry and wet condition.

In this study, the optimal model parameters performance was tested over the calibration and validation seasons as well as over the dry (November to May) and wet (June to October) periods. The SPI analysis was used to understand the rainfall variability throughout the study period and it indicated that $75 \%$ of the study period the annual rainfall received by both subbasins is considered as normal rainfall. A normal rainfall year is where the annual rainfall is within one standard deviation from the long-term mean annual rainfall. The moderately wet and dry conditions were represented by $12.5 \%$ each. The SPI indicated that the calibration and validation period encompasses a contrasting climate periods (normal, wet and dry periods). Therefore, the optimal model parameters can be used to study the impact of projected climate change.

\subsubsection{Future Climate Data}

Climate scenarios are used to understand the plausible future climate. They are also used to quantify the relative change in the current and future climate, which is often used as an input to the hydrological models to assess the impact of climate change on hydrological systems, for example as in this study. A global climate prediction model from Hadley Centre Coupled Model version 3 (HadCM3, Exeter, United Kingdom) downscaled with a Statistical Downscaling Model (SDSM) was used as input to a hydrological model to access the impact of future climate of the streamflow hydrology.

\section{General Circulation Model (GCM)}

There are different climate scenarios for climate change studies [37-41]. GCM based scenario [42,43] and Synthetic scenario [2] are often used to project future climate [38,41,44]. This study used a general circulation model (GCM) based scenario to predicted the effect of future climate on the river flow. Scenario-based GCMs are the most common method of developing climate scenarios to quantify and assess the plausible impact of climate change. GCMs are required to project and quantify the relative change of climate variables between the current and future time horizon [42,43].

Several GCM models include atmosphere, ocean, land surface and sea ice components [45]. This study used the Hadley Center Coupled Model version 3 (HadCM3), which is a coupled atmosphere-ocean model. HadCM3 is developed at the Hadley Center of the United Kingdom National Meteorological Service. The atmospheric component of the model has a horizontal resolution of $2.5^{\circ}$ by $3.75^{\circ}$, equivalent to a resolution of $278 \mathrm{~km}$ by $295 \mathrm{~km}$ with 19 vertical levels [46]. HadCM3 was selected because of its wide applications, good performance and free availability [19,47,48]. In 1996, the IPCC developed four different storylines emission scenarios, as described in Appendix A. In this study, scenario A2 and B2 were used. A2 scenario is based on high population growth and describes 
a very heterogeneous world with a high population growth, while B2 represents a world with an emphasis on a local solution to a continuous global population increase at a rate lower than A2 [49].

Statistical Downscaling Models (SDSM)

GCMs have limited application at a local scale due to their coarser spatial resolution [50]. The SDSM was used to downscale coarse resolution GCM climate data to local or watershed level application. The SDSM involves developing a quantitative relationship between large-scale atmospheric variables (predictors) and local surface variables (predictands) [51]. The predictor variables provide daily information about large-scale atmosphere condition, while the predictand describes the condition at the local level [32,52]. The predictor variables used to downscale the HadCM3 is described on Wilby and Dawson [53]. The description provides large-scale climate predictor variables for the base period as well as for projected time horizons.

SDSM requires a long-term meteorological data to develop multiple linear regression equations between the predictor and predictand [32,52]. The Dangila climatic station, which has a longer period of recorded data for rainfall and the maximum/minimum temperature, was used to downscale HadCM3 future climate data of A2 and B2 emission scenarios. The predictor variables, which have explained the variance of the predictands for the base period, were selected. The correlation was further filtered with a scatter plot to check whether the relationship was developed with few outliers or not. The regression indicated a strong correlation between the predictor variables relative humidity at $500 \mathrm{hpa}$ and near-surface relative humidity with precipitation and minimum temperature indicated a strong association with 500 hpa geopotential height, surface specific humidity and mean temperature at $2 \mathrm{~m}$ while maximum temperature indicated a strong correlation with 500 hpa zonal velocity, 500 hpa geopotential height and mean temperature at $2 \mathrm{~m}$. The performance of the downscaling was evaluated using the observed historical data for the baseline period. The downscaled data include rainfall, maximum and minimum temperatures for the study site. A classical baseline period of 30 years from 1961 to 1990 was adopted to represent present climate, as recommended by World Meteorological Organization [54]. The calibrated and validated SDSM model was used to predict the future climate for three-time horizons: 2020-2045 (2030s), 2045-2070 (2060s), and 2070-2100 (2080s). The potential evapotranspiration for the baseline and for the future time horizons was estimated using the FAO modified Penman-Monteith approach [24].

\section{Results and Discussion}

\subsection{Model Calibration and Validation}

The HBV model calibration showed a reasonable agreement with an NSE of 0.66 and 0.64 for Main Beles and Gilgel Beles, respectively. Figure 3A,B shows a comparison of simulated and observed daily streamflow of Main Beles and Gilgel Beles for the calibration period, respectively. Table 1 presents the calibrated model parameters and the corresponding statistical goodness-of-fit of Main and Gilgel Beles subbasins.

Table 1. HBV model calibrated parameters and model performance for the Main and Gilgel Beles subbasins.

\begin{tabular}{|c|c|c|c|c|c|c|c|c|c|c|}
\hline Parameter & Alfa (-) & Beta (-) & $\begin{array}{c}\text { FC } \\
(\mathrm{mm})\end{array}$ & $\begin{array}{c}\mathrm{K} 4 \\
\left(\mathrm{day}^{-1}\right)\end{array}$ & $\begin{array}{c}\text { KHQ } \\
\left(\text { day }^{-1}\right)\end{array}$ & LP (-) & $\begin{array}{c}\text { PERC } \\
\text { (mm/day) }\end{array}$ & $\begin{array}{c}\text { NSE } \\
(-)\end{array}$ & $\begin{array}{c}\text { PBIAS } \\
(\%)\end{array}$ & R-Square \\
\hline Main Beles & 1.1 & 1 & 1200 & 0.002 & 0.082 & 0.82 & 0.4 & 0.64 & -10 & 0.66 \\
\hline Gilgel Beles & 0.75 & 1 & 450 & 0.002 & 0.08 & 0.76 & 0.55 & 0.66 & -5 & 0.67 \\
\hline
\end{tabular}



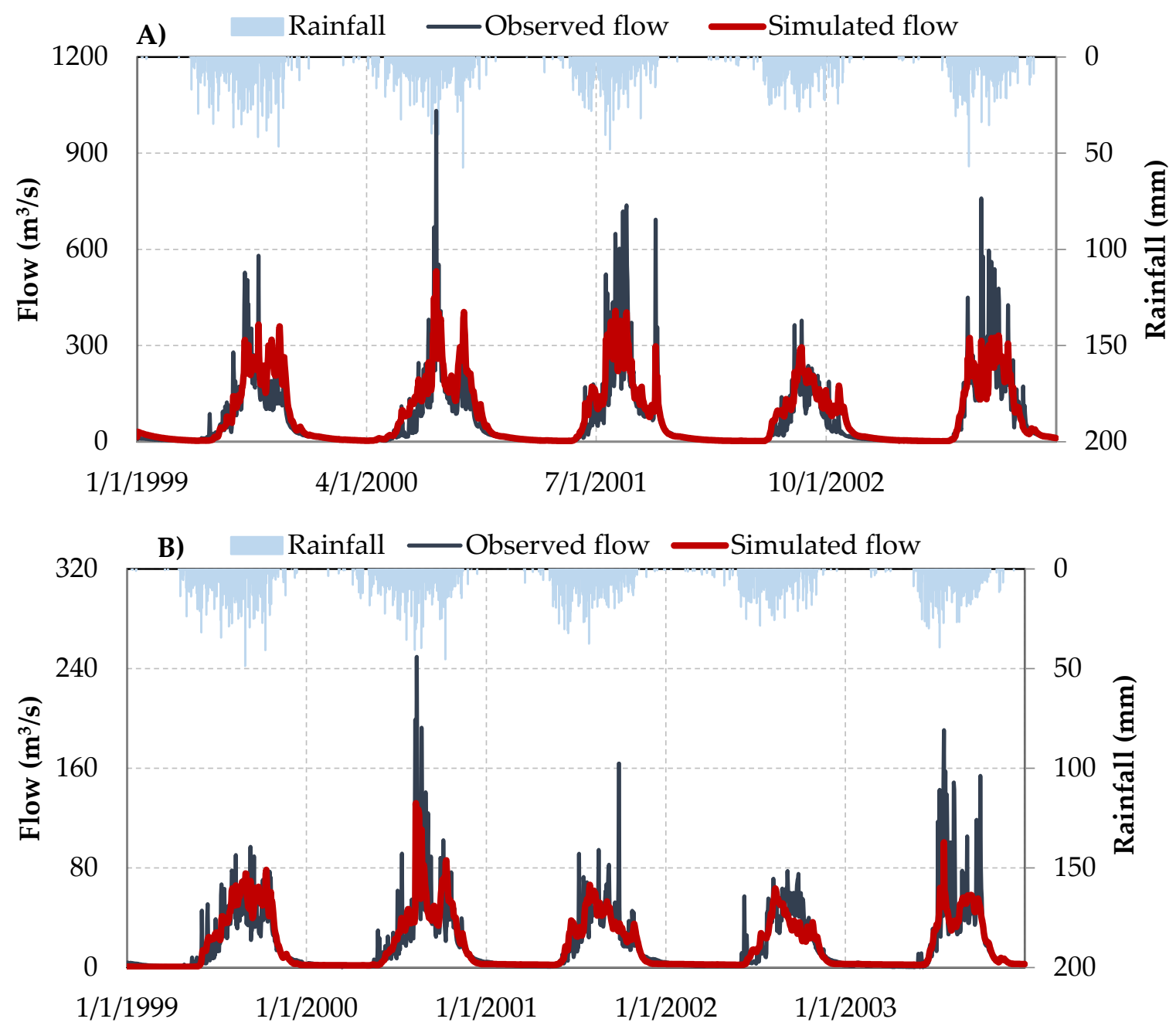

Figure 3. Comparison of simulated and observed flow for the calibration period (1999-2003): (A) simulated and observed flow of Main Beles for the calibration period; and (B) simulated and observed flow of Gilgel Beles for the calibration period.

The simulation for the calibration period did not capture peak flows very well. The single peaked high streamflows are often associated with extremely high rainfall events and perhaps occur at a time scale smaller than the daily time step of the simulation period. Peak flows often occur after the catchment's time of concentration is reached, which occurs after the entire or a large portion of the catchment contributed streamflow to the subbasin outlet. However, for this study, only three rainfall gauging stations located outside of the subbasins are used to represent the subbasins areal rainfall while the streamflow was observed twice a day. Hence, rainfall is highly spatially variable in this area [28,55-57], and the rainfall data used for this study might not be fully representative of the rainfall spatial and temporal pattern. The areal rainfall plotted in the secondary $y$-axis of Figure 3A,B also indicated a mismatch between peak rainfall and peak runoff. This may increase the uncertainty in the spatial distribution of runoff and lead to underestimation of the peaks.

The performance of the simulated streamflow over the wet and dry season is shown in Table 2. Overall, the simulated streamflow best captured the observed flow in the dry season for both rivers compared to the wet season flow, especially using the NSE and R-squared goodness-of-fit evaluation statistics. 
Table 2. Seasonal performance of HBV simulated streamflow vs. observed streamflow for the calibration and validation period of Main and Gilgel Beles subbasins.

\begin{tabular}{ccccccc}
\hline \multirow{2}{*}{ Calibration Period (1999 to 2003) } & \multicolumn{2}{c}{ Dry Season (November to May) } & \multicolumn{3}{c}{ Wet Season (June to October) } \\
\cline { 2 - 7 } & NSE (-) & PBIAS (\%) & R-Square & NSE (-) & PBIAS (\%) & R-Square \\
\hline Main Beles & 0.66 & -10 & 0.71 & 0.60 & -9 & 0.62 \\
Gilgel Beles & 0.68 & 6 & 0.72 & 0.52 & -3 & 0.52 \\
\hline Validation Period (2004 \& 2005) & NSE (-) & PBIAS (\%) & R-Square & NSE (-) & PBIAS (\%) & R-Square \\
\hline Main Beles & 0.82 & -9 & 0.79 & 0.50 & -3 & 0.51 \\
Gilgel Beles & 0.68 & -8 & 0.56 & 0.52 & 8 & 0.57 \\
\hline
\end{tabular}

The calibrated model parameters of Main Beles and Gilgel Beles were similar except for the maximum soil moisture holding capacity of the soil (FC) (Table 1). FC value of Main Beles was more than double that of Gilgel Beles. This was exhibited in the observed streamflow where the runoff yield of Gilgel Beles $(800 \mathrm{~mm})$ was close to two folds of Main Beles. The high FC value in the Main Beles suggests that a significant amount of water can be retained in the soil, which will be lost later via evapotranspiration and/or as baseflow compared to Gilgel Beles.

The calibrated models were evaluated with an independent input data for the period from 2004 to 2005, and the result showed that the calibrated model performed reasonably well with an NSE value of 0.75 and 0.61 for Main Beles and Gilgel Beles, respectively (Figure 4A,B). Therefore, the calibrated models together with downscaled future climate data were used to study the impact of future climate data on streamflow.
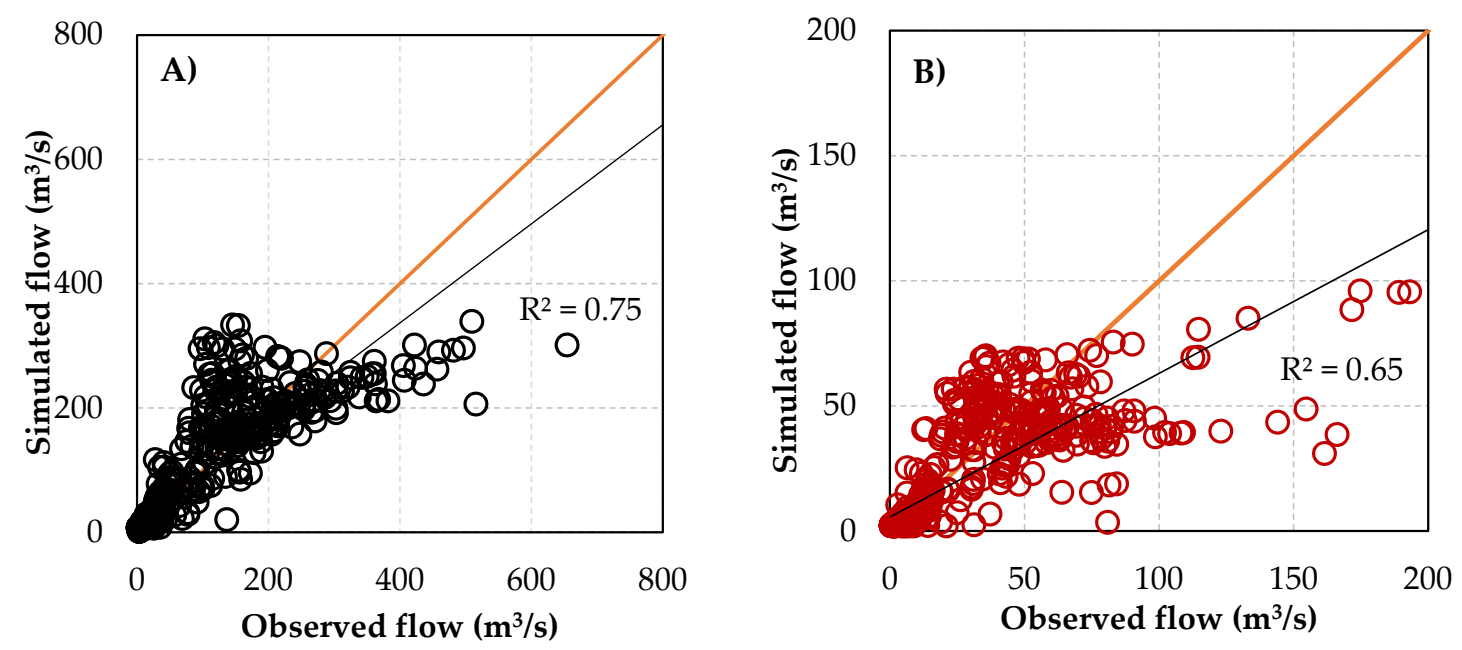

Figure 4. Scatter plot of observed and simulated flow for the validation period: (A) Main Beles simulated flow performance for the validation period; and (B) Gilgel Beles simulated flow performance for the validation period.

\subsection{Future Climate Data}

\subsubsection{Downscaled Precipitation, Maximum and Minimum Temperature for the Baseline Period}

The downscaled maximum and minimum temperature for the baseline period using HadCM3A2a and HadCM3B2a model outputs captured the observed monthly temperature distribution reasonably well. The model error calculated as the difference between monthly average downscaled and observed data was used to evaluate the performance of minimum and maximum temperature (Figure 5A,B). The maximum temperature was overpredicted by both models in February and March while underpredicted in April to August, November, and December (Figure 5A). The maximum difference between predicted and observed maximum temperature for both model outputs were $0.5^{\circ} \mathrm{C}$, which occurred in February (in the dry season). In both models, the monthly minimum temperature 
was overpredicted, except in June, July, and December (Figure 5B). The minimum temperature was underpredicted in the major rainfall season (wet season). The maximum model output difference between predicted and observed minimum temperature in both model outputs was $\sim 0.5{ }^{\circ} \mathrm{C}$ in September and October (wet season). The difference between predicted and observed long-term monthly maximum/minimum temperatures between the two models were not significantly different. Therefore the downscaled temperature from both model outputs could be used to predict the future temperature in both subbasins. The performance of the downscaled minimum temperature for the base period indicated a consistency bias for both emission scenarios by under predicting the observed data. The consistent under prediction could be easily bias corrected with a linear bias correction [26]. While maximum temperature did not show a consistent bias, in this case, bias could be corrected with histogram matching, gamma or power transformation functions among others [48,58-60].
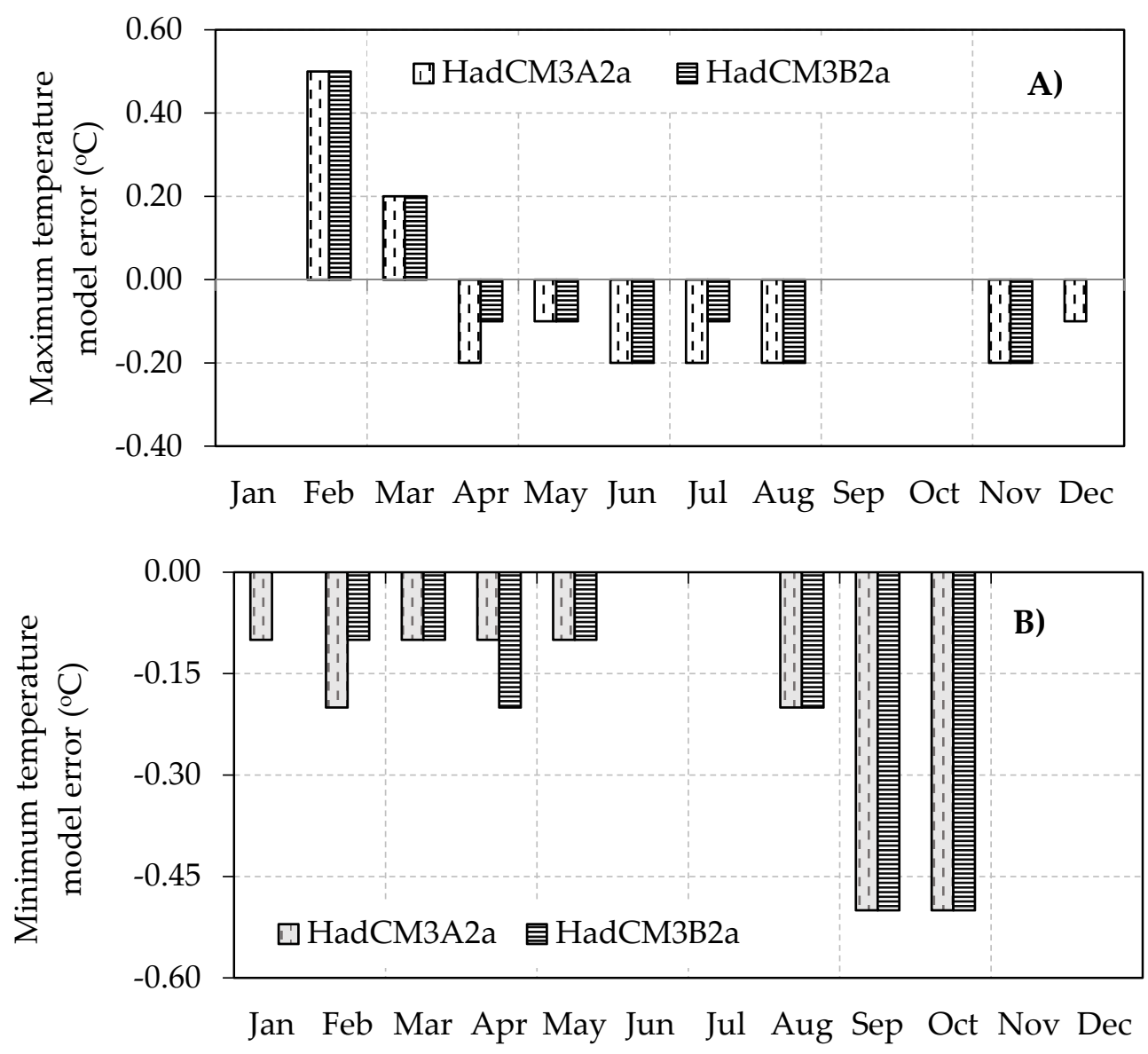

Figure 5. The HadCM3A2a and HadCM3B2a model error of minimum and maximum temperature for the baseline period (1961-1990): (A) monthly minimum temperature difference between downscaled and observed for baseline period; and (B) maximum temperature difference between downscaled and observed for the baseline period.

The observed rainfall amounts were not reasonably captured by either of the downscaled climate scenarios because of the complex rainfall formation process [20]. Moreover, the coarse spatial resolution of the GCM models makes it difficult to adequately capture the observed rainfall pattern $[19,61]$. Both scenarios overpredicted rainfall in the dry season while underestimating in the major rainfall season (Figure 6). The difference between average monthly observed and predicted rainfall was $\sim 9.9 \mathrm{~mm} /$ month and $13.5 \mathrm{~mm} /$ month for HadCM3A2a and HadCM3B2a model outputs, respectively. Even though there was some difference between the observed and predicted rainfall for the baseline period, the HadCM3A2a model output was better in capturing the temporal variation of the observed 
rainfall than the HadCM3B2a model output. Therefore, the HadCM3A2a model output (medium-high emission) was chosen to study the impact of future climate on the streamflow.

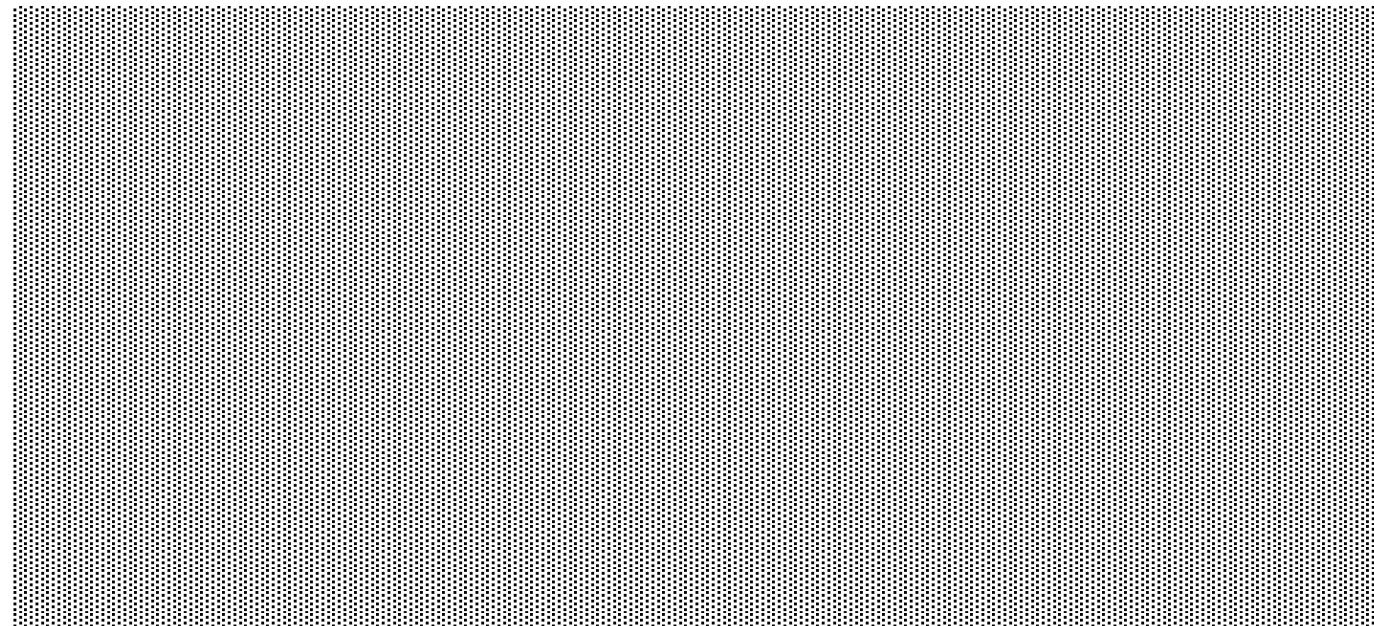

Figure 6. Downscaled precipitation of HadCM3A2a and HadCM3B2a model error from the baseline period (1961 to 1990).

\subsubsection{Downscaled Precipitation, Maximum and Minimum Temperature for Future Time Horizon}

The projected maximum and minimum temperature from A2 scenario showed an increasing trend for all future time horizons (Figures 7 and 8). In the A2 scenario, the projected temperature in the 2030s indicated that maximum and minimum temperature may increase by 0.6 and $1.0^{\circ} \mathrm{C}$ from the baseline period. In the 2060s, the maximum and minimum temperature will increase by $2.2^{\circ} \mathrm{C}$ and $1.4^{\circ} \mathrm{C}$ from the baseline period, respectively. In the 2080s, the maximum and minimum temperature will increase by 2.4 and $3.6^{\circ} \mathrm{C}$ from the baseline period. For the future time horizons, the rate of change of maximum temperature will be greater than the minimum monthly temperature.

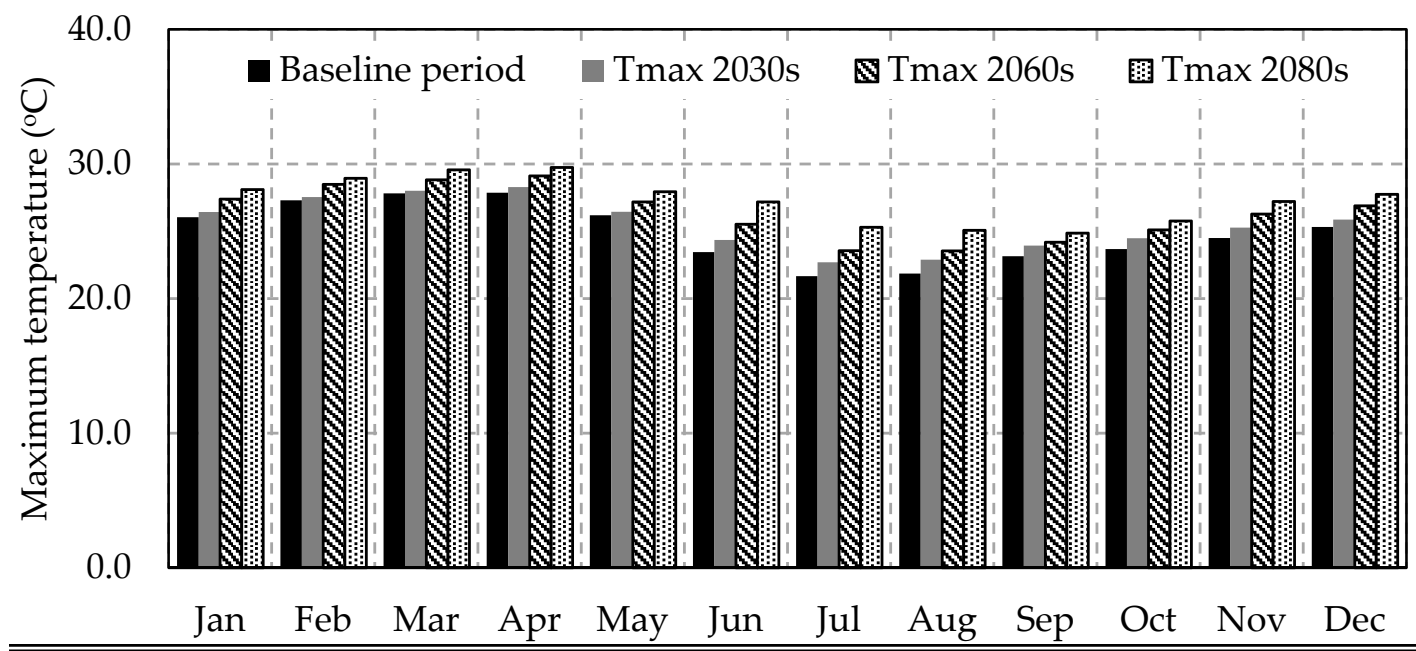

Figure 7. Long-term average monthly maximum temperature for baseline period and future time horizons (2030s, 2060s and 2080s) in the Main Beles and Gilgel Beles subbasins. 


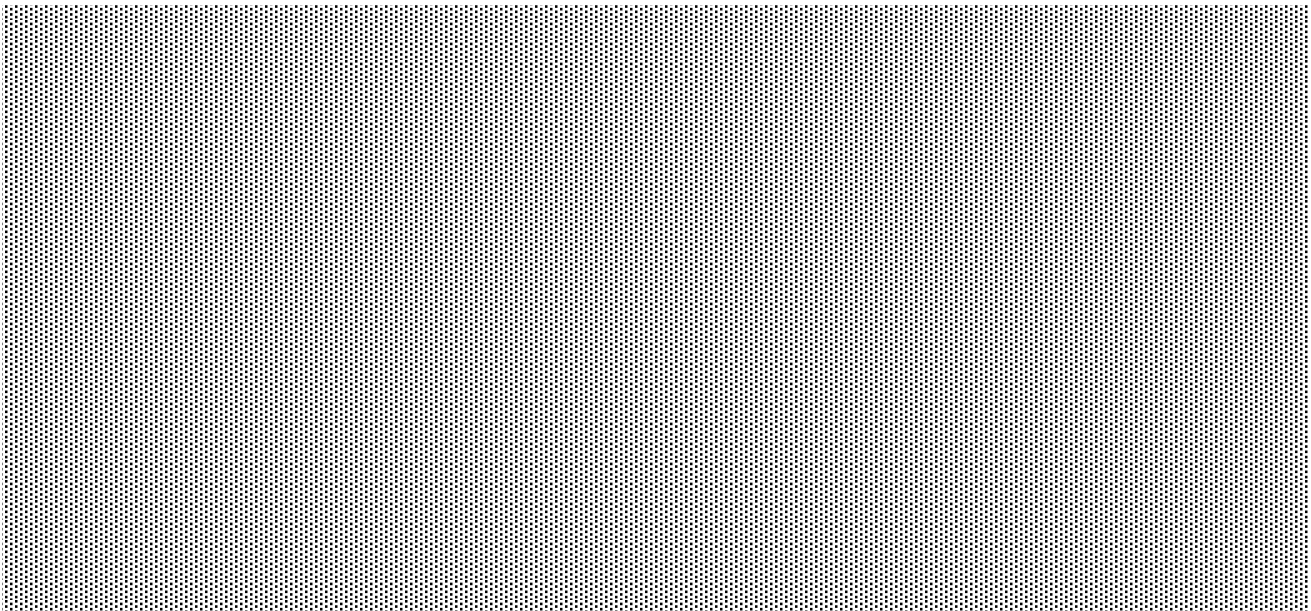

Figure 8. Long-term average monthly minimum temperature for baseline period and future time horizons (2030s, 2060s, and 2080s) in the Main Beles and Gilgel Beles subbasins.

The long-term average monthly potential evapotranspiration was estimated for the baseline period and for the projected time horizons using the maximum and minimum temperature (Figure 9). The result indicated that the potential evapotranspiration might increase throughout the coming century. The average monthly potential evapotranspiration may increase by $2 \%, 4.7 \%$, and $7.8 \%$, in the 2030s, 2060s, and 2080s, respectively. The increasing temperature due to climate change may affect soil water balance by increasing soil evaporation and plant transpiration, thereby affecting crop growth and agricultural productivity [62].

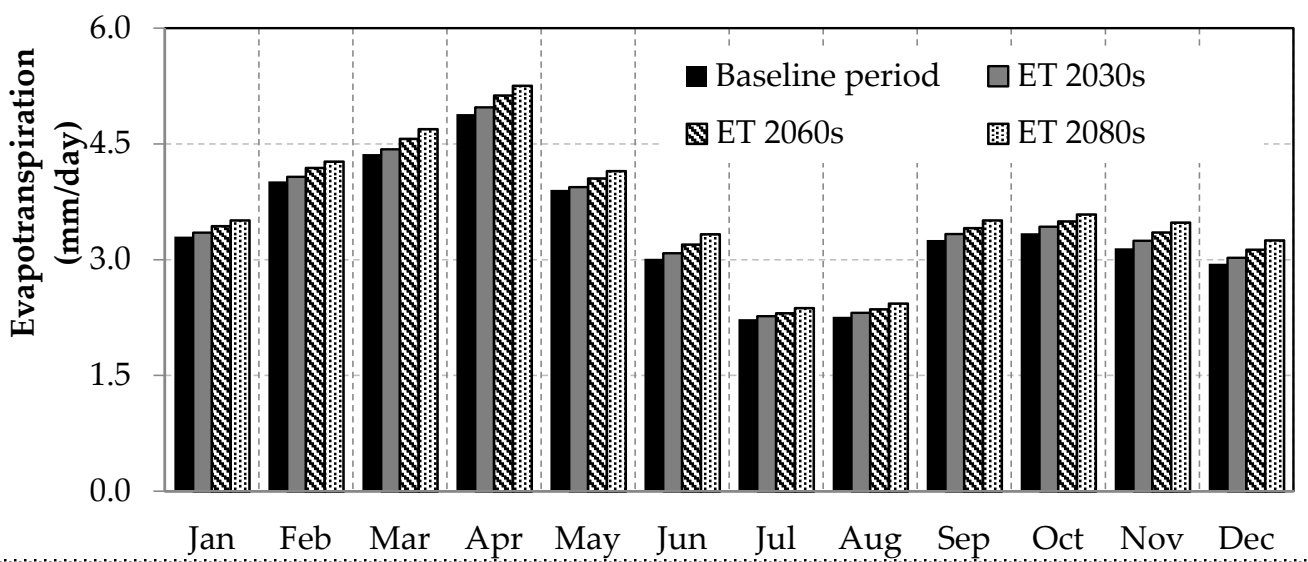

Figure 9. Long-term mean monthly potential evapotranspiration for baseline period and future time horizons (2030s, 2060s, and 2080s) in the Main Beles and Gilgel Beles subbasins.

The average annual projected rainfall was estimated to increase by $2.3 \%$ in the $2030 \mathrm{~s}$ and expected to increase by $2.6 \%$ and $3.1 \%$ in the 2060 s and 2080 s, respectively. However, the monthly rainfall projection for the coming century did not show a consistent trend, unlike the temperature, which has indicated a consistent increasing trend throughout all time horizons (Figure 10). The projected rainfall showed a decreasing trend in May and June (months before the beginning of the major rainfall season) and an increasing trend was observed in September, October and November (i.e., the months after the major rainfall season) in the three-time horizons. The major rainfall months (June and July) did not show a consistent trend. Therefore, this suggests that climate change may shift the rainfall pattern in the Main Beles and Gilgel Beles subbasins. Similar findings were captured by Abdo et al. [19], Dile et al. [20] and Adem et al. [39]. 


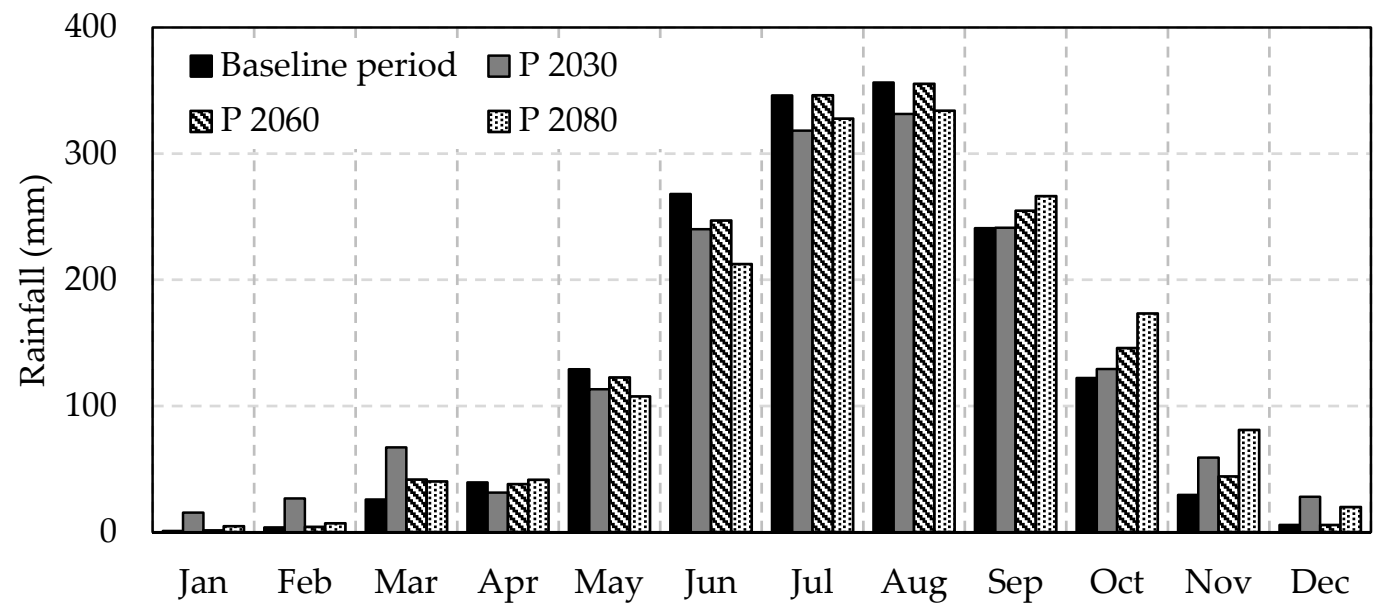

Figure 10. Average monthly rainfall during the baseline period and future time horizons (2030s, 2060s and 2080s) in the Main Beles and Gilgel Beles subbasins.

The projected rainfall showed an increasing rainfall trend in the dry season including October to March and a decreasing trend in April through June, which is not the major rainfall season. The increasing rainfall in the dry season may be used to supplement dry season irrigation.

\subsection{Impact of Climate Change on the Hydrology}

The projected rainfall, temperature, and potential evapotranspiration values were used as input to the calibrated and validated HBV model for each future time horizons. The HBV model was used to evaluate the impact of projected climate data on the hydrology of Main Beles and Gilgel Beles subbasins for the three-time horizons: 2030s, 2060s and 2080s.

Hydrological impact of climate change in the Main and Gilgel Beles estimated by the HBV is summarized in Table 3 and Figure 11A,B. Average annual streamflow may decrease from baseline period, during all time horizons 2030s, 2060s, and 2080s. The average annual streamflow may decrease by up to $4.9 \%$ in Main Beles subbasin in the 2080s. For Gigel Beles, streamflow will reduce by up to $5.4 \%$ during the 2030 s.

The seasonal variation of runoff of the projected climate from the baseline period was computed for wet and dry season (Table 3). The wet season includes June to September and the dry season includes the other eight months. The dry season average streamflow of Main Beles may increase by $45 \%, 16 \%$ and $64 \%$ from the baseline period in the 2030s, 2060s and 2080s, respectively. For Gilgel Beles, flow may increase by $44 \%, 16 \%$ and $65 \%$ in 2030s, 2060s and 2080s, respectively (Table 3 ). The average wet season streamflow may decrease for the coming century in both subbasins. For example, the average wet season streamflow for Main Beles will decrease by $11 \%, 7 \%$ and $19 \%$ in the 2030 s, 2060s, and 2080s, respectively. For Gilgel Beles, the average wet season flow will decrease by $12 \%, 6 \%$ and $17 \%$ in the 2030s, 2060s, and 2080s, respectively (Table 3).

Table 3. Average annual streamflow and change in average seasonal stream flow between the three-time horizons from the baseline period.

\begin{tabular}{ccccccccccc}
\hline \multirow{2}{*}{ Subbasins } & \multicolumn{3}{c}{$\begin{array}{c}\text { Annual Average Streamflow } \\
\text { Change (\%) }\end{array}$} & \multicolumn{3}{c}{$\begin{array}{c}\text { Change in Average Dry } \\
\text { Season Streamflow (\%) }\end{array}$} & \multicolumn{3}{c}{$\begin{array}{c}\text { Change in Average Wet } \\
\text { Season Streamflow (\%) }\end{array}$} \\
\cline { 2 - 11 } & 2030s & 2060s & 2080s & 2030s & 2060s & 2080s & 2030s & 2060s & 2080s \\
\hline Main Beles & -4.48 & -1.36 & -4.96 & 45 & 17 & 64 & -11 & -7 & -19 \\
Gilgel Beles & -5.40 & -0.59 & -3.52 & 44 & 16 & 65 & -12 & -6 & -17 \\
\hline
\end{tabular}




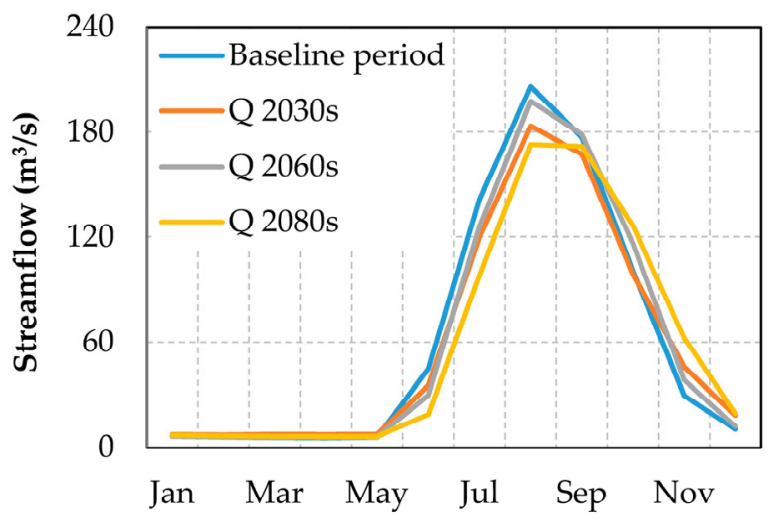

(A)

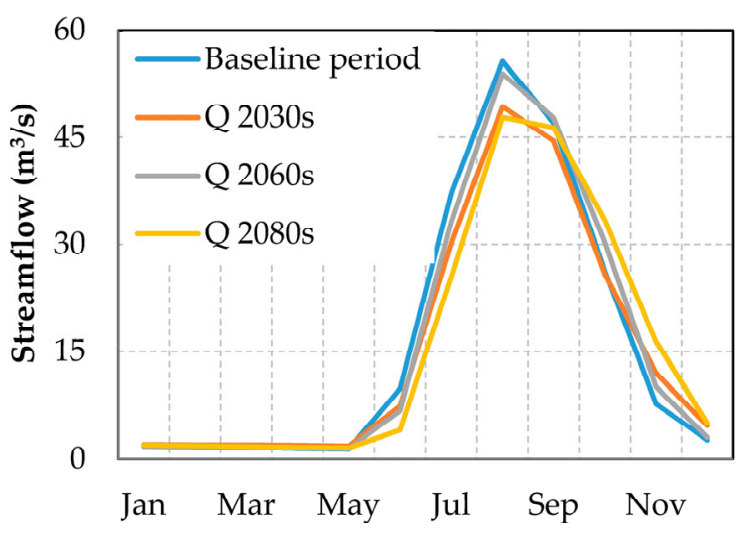

(B)

Figure 11. Average monthly streamflow for the baseline period and for the projected time horizon for: (A) Main Beles; and (B) Gilgel Beles.

The hydrograph for the monthly streamflow indicated that there may be an increase in both subbasins in the dry season. For example, in the 2030s, an increase in streamflow of up to $75 \%$ and 78\% was observed in December for Gilgel Beles and Main Beles, respectively. In the 2060s and 2080s, the largest monthly flow increase was observed in November in both subbasins.

\subsection{Limitation of the Study}

Impact of climate change study on streamflow applying hydrological models involves a range of uncertainties $[19,21,36,63]$. The various sources of uncertainties in climate change studies are ranked in various studies such as Wilby and Harris [36] and Chen et al. [64]. Selection of the GCM model and definitions of the emission scenarios are the greatest sources of uncertainty on climate change studies $[36,64,65]$. The disagreement between different GCM models over regional climate change studies is widely acknowledged as a significant source of uncertainty [36,53]. A significant difference in future climate data could arise when downscaling with dynamic and statistical downscaling methods $[36,66,67]$ or even within statistical downscaling methods due to the difference in spatial domains, predictor variables and predictands $[21,67]$. The other source of uncertainty is associated with the hydrological model, which is used to translate the impact of the future climate data to hydrological response (e.g., impact on streamflow). The hydrological uncertainty arises from model structure, parameter uncertainty, and data scarcity [68]. This study used one GCM model, two emission scenarios and a semi-distributed hydrological model to understand the effect of future climate on the water availability in upper Blue Nile basin. Despite the limitations, this study executed every effort (e.g., looking for the best available data, using the most possible plausible emission scenarios, etc.) to reduce the uncertainty on the model prediction and tried to understand the plausible impact of climate change on the water resource availability in the upper Blue Nile basin of Ethiopia.

\section{Conclusions}

The future climate and its impact on potential evapotranspiration and streamflow for Main Beles and Gilgel Beles subbasins are evaluated using downscaled A2 (medium-high) and B2 (medium-low) emission scenarios. The findings show a consistent increasing trend for both minimum and maximum temperature for all time horizons (2030s, 2060s and 2080s) with a higher rate of increase towards the end of the century. Results also show that the rate of change of maximum temperature is higher than the rate of change of minimum temperature. We have found that this will be responsible for alterations of the hydrological cycle by increasing the evapotranspiration by $2 \%$ in the $2030 \mathrm{~s}, 4.7 \%$ in the $2060 \mathrm{~s}$ and $7.8 \%$ at the end of the century. The increase in evapotranspiration suggests increased crop water requirement in future crop production. Thus, the design of irrigation infrastructure should take this 
into account. Moreover, larger storage structure is needed to offset the decline in the rainfall of the major rainfall season. The model output indicated that this change in the water balance component could severely affect streamflow of both rivers. The average annual streamflow could decrease in future time horizons compared to the baseline period. On a seasonal basis, the wet season flow will decrease for the coming century; reducing by $19 \%$ and $17 \%$ for Main and Gilgel Beles, respectively, at the end of the century. The dry season flow may increase by $64 \%$ and $65 \%$ for Main Beles and Gilgel Beles, respectively, by the end of the century. The monthly and seasonal version of streamflow is relatively higher than the annual flow variation.

Acknowledgments: This publication was made possible through support provided by Feed the Future through the U.S. Agency for International Development, under the terms of Contract No. AID-OAA-A-13-0005. The opinions expressed herein are those of the author(s) and do not necessarily reflect the views of the U.S. Agency for International Development. We would also like to acknowledge the National Meteorological Agency Services of Ethiopia and the Ethiopian Ministry of Water, Irrigation and Energy for providing daily streamflow and weather data, respectively for multiple site free of charge. Finally, we appreciate the editor and the three anonymous reviewers for their constrictive feedback.

Author Contributions: Abeyou Wale Worqlul designed the model calibration, validation and downscaling of the climate data. Abeyou Wale Worqlul, Yihun Taddele Dile, Essayas Kaba Ayana and Anwar Assefa Adem wrote the paper. Jaehak Jeong and Thomas Gerik supervised the research.

Conflicts of Interest: The authors declare no conflict of interest.

\section{Appendix The Special Report on Emission Scenarios (SRES)}

In 1996, the IPCC began the development of a new set of emission scenarios to effectively update and replace the well-known IS92 scenarios. The approved new set of scenarios is described in the IPCC special report on emission scenarios (SRES). Four different narrative storylines were developed to consistently describe the relationship between the forces driving emission and their evaluation and to add context for the scenario quantification. The resulting set of 40 scenarios covers the wide range of main demographic, economic and technological driving forces of future greenhouse gas and sulfur emissions. Each scenario represents the specific quantification of one of the four storylines. All scenarios based on the same storyline constitute a scenario "family", which briefly describe the main characteristics of the four SRES storylines and scenario family (IPCC-TGICA, 2007).

A1. The A1 storyline and scenario family describe a future world of very rapid economic growth, global population that peaks in mid-century and declines thereafter, and the rapid introduction of new and more efficient technologies. Major underlying themes are convergence among regions, capacity building and increased cultural and social interactions, with a substantial reduction in regional differences in per capita income. The A1 scenario family develops into three groups that describe alternative directions of technological change in the energy system. The three A1 groups are distinguished by their technological emphasis: Fossil intensive (A1FI), non-fossil energy sources (A1T); or Balance across all sources (A1B) (balanced is defined as not relying too heavily on one particular energy source, on the assumption that similar improvement rates apply to all energy supply and end use technologies).

A2. The A2 storyline and scenario family describe a very heterogeneous world. The underlying theme is self-reliance and preservation of local identities. Fertility patterns across regions converge very slowly, which results in continuously increasing population. Economic development is primarily regionally oriented and per capita economic growth and technological changes are more fragmented and slower than in other storylines.

B1. The B1 storyline and scenario family describe a convergent world with the same global population, which peaks in mid-century and declines thereafter, as in the A1 storyline, but with rapid change in economic structures toward a service and information economy, with reductions in material intensity and the introduction of clean and resource-efficient technologies. The emphasis is on global solutions to economic, social and environmental sustainability, including improved equity, but without additional climate initiatives. 
B2. The B2 storyline and scenario family describe a world in which the emphasis is on local solutions to economic, social and environmental sustainability. It is a world with continuously increasing global population at a rate lower than A2, intermediate levels of economic development, and less rapid and more diverse technological change than in the B1 and A1 storylines. The scenario is also oriented towards environmental protection.

\section{References}

1. Ramaswamy, V.; Boucher, O.; Haigh, J.; Hauglustine, D.; Haywood, J.; Myhre, G.; Nakajima, T.; Shi, G.; Solomon, S. Radiative forcing of climate change. In Climate Change 2001: The Scientific Basis Clim; Cambridge University Press: Cambridge, UK; New York, NY, USA, 2001; pp. 349-416.

2. Intergovernmental Panel on Climate Change (IPCC). Climate Change 2001: The Scientific Basis; Houghton, J.T., Ding, Y., Griggs, D.J., Noguer, M., van der Linden, P.J., Dai, X., Maskell, K., Johnson, C.A., Eds.; Cambridge University Press: Cambridge, UK; New York, NY, USA, 2001; 881p.

3. Prentice, I.C.; Farquhar, G.; Fasham, M.; Goulden, M.; Heimann, M.; Jaramillo, V.; Kheshgi, H.; LeQuéré, C.; Scholes, R.; Wallace, D.W. The carbon cycle and atmospheric carbon dioxide. In Climate Change 2001: The Scientific Basis Clim; Cambridge University Press: Cambridge, UK; New York, NY, USA, 2001.

4. McMichael, A.J. Global climate change and health: An old story writ large. In Climate Change and Human Health: Risks and Responses; World Health Organization: Geneva, Switzerland, 2003.

5. Hoegh-Guldberg, O.; Bruno, J.F. The impact of climate change on the world's marine ecosystems. Science 2010, 328, 1523-1528. [PubMed]

6. Preston, B.L.; Jones, R.N. Climate Change Impacts on Australia and the Benefits of Early Action to Reduce Global Greenhouse Gas Emissions; A consultancy report for the Australian Business Roundtable on Climate Change; The Commonwealth Scientific and Industrial Research Organisation (CSIRO): Canberra, Australia, 2006.

7. Rahmstorf, S.; Coumou, D. Increase of extreme events in a warming world. Proc. Natl. Acad. Sci. USA 2011, 108, 17905-17909. [PubMed]

8. Coumou, D.; Rahmstorf, S. A decade of weather extremes. Nat. Clim. Chang. 2012, 2, 491-496.

9. Intergovernmental Panel on Climate Change (IPCC). Managing the Risks of Extreme Events and Disasters to Advance Climate Change Adaptation: Special Report of the Intergovernmental Panel on Climate Change; Cambridge University Press: New York, NY, USA, 2012.

10. Parry, M.L.; Canziani, O.; Palutikof, J.P.; van der Linden, P.J.; Hanson, C.E. (Eds.) Contribution of Working Group II to the Fourth Assessment Report of the Intergovernmental Panel on Climate Change, 2007; Climate change; Cambridge University Press: Cambridge, UK; New York, NY, USA, 2007.

11. Worqlul, A.W.; Jeong, J.; Dile, Y.T.; Osorio, J.; Schmitter, P.; Gerik, T.; Srinivasan, R.; Clarke, N. Assessing potential land suitable for surface irrigation using groundwater in Ethiopia. Appl. Geogr. 2017, 85, 1-13.

12. Worqlul, A.W.; Collick, A.S.; Rossiter, D.G.; Langan, S.; Steenhuis, T.S. Assessment of surface water irrigation potential in the Ethiopian highlands: The Lake Tana basin. Catena 2015, 129, 76-85.

13. Shiferaw, B.; Holden, S.T. Resource degradation and adoption of land conservation technologies in the Ethiopian highlands: A case study in Andit Tid, north Shewa. Agric. Econ. 1998, 18, 233-247.

14. Olesen, J.E.; Bindi, M. Consequences of climate change for European agricultural productivity, land use and policy. Eur. J. Agron. 2002, 16, 239-262.

15. Vörösmarty, C.J.; Green, P.; Salisbury, J.; Lammers, R.B. Global water resources: Vulnerability from climate change and population growth. Science 2000, 289, 284-288. [PubMed]

16. McMichael, A.J.; Powles, J.W.; Butler, C.D.; Uauy, R. Food, livestock production, energy, climate change, and health. The Lancet 2007, 370, 1253-1263.

17. Indian People Organizing for Change (IPOC). Climate Change 2014-Impacts, Adaptation and Vulnerability: Regional Aspects; Cambridge University Press: Cambridge, UK; New York, NY, USA, 2014.

18. Hattermann, F.F.; Post, J.; Krysanova, V.; Conradt, T.; Wechsung, F. Assessment of water availability in a Central-European River basin (Elbe) under climate change. Adv. Clim. Chang. Res. 2008, 4, 42-50.

19. Abdo, K.; Fiseha, B.; Rientjes, T.; Gieske, A.; Haile, A. Assessment of climate change impacts on the hydrology of Gilgel Abay catchment in Lake Tana basin, Ethiopia. Hydrol. Process. 2009, 23, 3661-3669.

20. Dile, Y.T.; Berndtsson, R.; Setegn, S.G. Hydrological response to climate change for Gilgel Abay River, in the Lake Tana basin-upper Blue Nile basin of Ethiopia. PLOS ONE 2013, 8, e79296. 
21. Fowler, H.J.; Blenkinsop, S.; Tebaldi, C. Linking climate change modelling to impacts studies: Recent advances in downscaling techniques for hydrological modelling. Int. J. Climatol. 2007, 27, 1547-1578.

22. Christensen, N.S.; Wood, A.W.; Voisin, N.; Lettenmaier, D.P.; Palmer, R.N. The effects of climate change on the hydrology and water resources of the Colorado River basin. Clim. Chang. 2004, 62, 337-363.

23. Svoboda, M.; Hayes, M.; Wood, D. Standardized Precipitation Index User Guide; World Meteorological Organization: Geneva, Switzerland, 2012.

24. Penman, H.L. Natural evaporation from open water, bare soil and grass. In Proceedings of the Royal Society of London A: Mathematical, Physical and Engineering Sciences; The Royal Society: London, UK, 1948; pp. 120-145.

25. Michéli, E.; Schad, P.; Spaargaren, O. World Reference Base for Soil Resources 2006: A Framework for International Classification, Correlation and Communication; Food and agriculture organization of the United Nations (FAO): Rome, Italy, 2006.

26. Lindström, G.; Johansson, B.; Persson, M.; Gardelin, M.; Bergström, S. Development and test of the distributed HBV-96 hydrological model. J. Hydrol. 1997, 201, 272-288. [CrossRef]

27. Worqlul, A.W.; Ayana, E.K.; Maathuis, B.H.; MacAlister, C.; Philpot, W.D.; Leyton, J.M.O.; Steenhuis, T.S. Performance of bias corrected MPEG rainfall estimate for rainfall-runoff simulation in the upper Blue Nile basin, Ethiopia. J. Hydrol. 2018, 556, 1182-1191. [CrossRef]

28. Worqlul, A.W.; Yen, H.; Collick, A.S.; Tilahun, S.A.; Langan, S.; Steenhuis, T.S. Evaluation of CFSR, TMPA 3B42 and ground-based rainfall data as input for hydrological models, in data-scarce regions: The upper Blue Nile basin, Ethiopia. Catena 2017, 152, 242-251. [CrossRef]

29. Uhlenbrook, S.; Mohamed, Y.; Gragne, A. Analyzing catchment behavior through catchment modeling in the Gilgel Abay, upper Blue Nile River basin, Ethiopia. Hydrol. Earth Syst. Sci. 2010, 14, 2153-3165. [CrossRef]

30. Gebrehiwot, S.G.; Seibert, J.; Gärdenäs, A.I.; Mellander, P.E.; Bishop, K. Hydrological change detection using modeling: Half a century of runoff from four rivers in the Blue Nile basin. Water Resour. Res. 2013, 49, 3842-3851. [CrossRef]

31. Rientjes, T.; Perera, B.; Haile, A.; Reggiani, P.; Muthuwatta, L. Regionalisation for lake level simulation-the case of Lake Tana in the upper Blue Nile, Ethiopia. Hydrol. Earth Syst. Sci. 2011, 15, 1167-1183. [CrossRef]

32. Wilby, R.; Charles, S.P.; Zorita, E.; Timbal, B.; Whetton, P.; Mearns, L.O. Guidelines for Use of Climate Scenarios Developed from Statistical Downscaling Methods. Supporting Material of the Intergovernmental Panel on Climate Change: Geneva, Switzerland, August 2004.

33. Wale, A.; Rientjes, T.; Gieske, A.; Getachew, H. Ungauged catchment contributions to Lake Tana's water balance. Hydrol. Process. 2009, 23, 3682-3693. [CrossRef]

34. Swedish Meteorological and Hydrological Institute (SMHI). Integrated Hydrological Modelling System (IHMS). Manual Version 5.10; Swedish Meteorological and Hydrological Institute: Norrköping, Swedish, 2006.

35. Klemeš, V. Operational testing of hydrological simulation models. Hydrol. Sci. J. 1986, 31, 13-24. [CrossRef]

36. Wilby, R.L.; Harris, I. A framework for assessing uncertainties in climate change impacts: Low-flow scenarios for the River Thames, UK. Water Resour. Res. 2006, 42. [CrossRef]

37. Prudhomme, C.; Wilby, R.; Crooks, S.; Kay, A.; Reynard, N. Scenario-neutral approach to climate change impact studies: Application to flood risk. J. Hydrol. 2010, 390, 198-209. [CrossRef]

38. Strandman, H.; Väisänen, H.; Kellomäki, S. A procedure for generating synthetic weather records in conjunction of climatic scenario for modelling of ecological impacts of changing climate in boreal conditions. Ecol. Model. 1993, 70, 195-220. [CrossRef]

39. Adem, A.A.; Melesse, A.M.; Tilahun, S.A.; Setegn, S.G.; Ayana, E.K.; Wale, A.; Assefa, T.T. Climate change projections in the upper Gilgel Abay River catchment, Blue Nile basin Ethiopia. In Nile River Basin; Springer: Berlin, Germany, 2014; pp. 363-388.

40. Wilby, R.L.; Wigley, T. Downscaling general circulation model output: A review of methods and limitations. Prog. Phys. Geogr. 1997, 21, 530-548. [CrossRef]

41. Liang, X.; Lettenmaier, D.P.; Wood, E.F.; Burges, S.J. A simple hydrologically based model of land surface water and energy fluxes for general circulation models. J. Geophys. Res. Atmos. 1994, 99, 14415-14428. [CrossRef]

42. Dibike, Y.B.; Coulibaly, P. Hydrologic impact of climate change in the Saguenay watershed: Comparison of downscaling methods and hydrologic models. J. Hydrol. 2005, 307, 145-163. [CrossRef]

43. Roudier, P.; Sultan, B.; Quirion, P.; Berg, A. The impact of future climate change on West African crop yields: What does the recent literature say? Glob. Environ. Chang. 2011, 21, 1073-1083. [CrossRef] 
44. Liuzzo, L.; Noto, L.V.; Vivoni, E.R.; La Loggia, G. Basin-scale water resources assessment in Oklahoma under synthetic climate change scenarios using a fully distributed hydrologic model. J. Hydrol. Eng. 2009, 15, 107-122. [CrossRef]

45. Cox, P.M.; Betts, R.A.; Jones, C.D.; Spall, S.A.; Totterdell, I.J. Acceleration of global warming due to carbon-cycle feedbacks in a coupled climate model. Nature 2000, 408, 184-187. [CrossRef] [PubMed]

46. Gordon, C.; Cooper, C.; Senior, C.A.; Banks, H.; Gregory, J.M.; Johns, T.C.; Mitchell, J.F.; Wood, R.A. The simulation of SST, sea ice extents and ocean heat transports in a version of the Hadley Centre coupled model without flux adjustments. Clim. Dyn. 2000, 16, 147-168. [CrossRef]

47. Zhu, Q.; Zhang, X.; Ma, C.; Gao, C.; Xu, Y.-P. Investigating the uncertainty and transferability of parameters in SWAT model under climate change. Hydrol. Sci. J. 2016, 61, 914-930. [CrossRef]

48. Teutschbein, C.; Seibert, J. Bias correction of regional climate model simulations for hydrological climate-change impact studies: Review and evaluation of different methods. J. Hydrol. 2012, 456, 12-29. [CrossRef]

49. Mearns, L.; Hulme, M.; Carter, T.; Leemans, R.; Lal, M.; Whetton, P.; Hay, L.; Jones, R.; Kittel, T.; Smith, J.; et al. Climate scenario development. In Climate Change 2001: The Science of Climate Change; Cambridge University Press: Cambridge, UK, 2001; pp. 739-768.

50. Adem, A.A.; Tilahun, S.A.; Ayana, E.K.; Worqlul, A.W.; Assefa, T.T.; Dessu, S.B.; Melesse, A.M. Climate change impact on sediment yield in the upper Gilgel Abay catchment, Blue Nile basin, Ethiopia. In Landscape Dynamics, Soils and Hydrological Processes in Varied Climates; Springer: Cham, Switzerland, 2016; pp. 615-644.

51. Wilby, R.L.; Dawson, C.W. SDSM 4.2-A Decision Support Tool for the Assessment of Regional Climate Change Impacts; User Manual: London, UK, 2007.

52. Ghosh, S.; Mujumdar, P.P. Statistical downscaling of GCM simulations to streamflow using relevance vector machine. Adv. Water Resour. 2008, 31, 132-146. [CrossRef]

53. Wilby, R.L.; Dawson, C.W. The statistical downscaling model: Insights from one decade of application. Int. J. Climatol. 2013, 33, 1707-1719. [CrossRef]

54. World Meteorological Organization (WMO). Wmo Statement on the State of the Global Climate in 2016; WMO: Geneva, Switzerland, 2017.

55. Tilahun, K. Analysis of rainfall climate and evapo-transpiration in arid and semi-arid regions of Ethiopia using data over the last half a century. J. Arid Environ. 2006, 64, 474-487. [CrossRef]

56. Cheung, W.H.; Senay, G.B.; Singh, A. Trends and spatial distribution of annual and seasonal rainfall in Ethiopia. Int. J. Climatol. 2008, 28, 1723-1734. [CrossRef]

57. Worqlul, A.W.; Maathuis, B.; Adem, A.A.; Demissie, S.S.; Langan, S.; Steenhuis, T.S. Comparison of rainfall estimations by TRMM 3B42, MPEG and CFSR with ground-observed data for the Lake Tana basin in Ethiopia. Hydrol. Earth Syst. Sci. 2014, 18, 4871-4881. [CrossRef]

58. Berg, P.; Feldmann, H.; Panitz, H.-J. Bias correction of high resolution regional climate model data. J. Hydrol. 2012, 448, 80-92. [CrossRef]

59. Habib, E.; Haile, A.T.; Sazib, N.; Zhang, Y.; Rientjes, T. Effect of bias correction of satellite-rainfall estimates on runoff simulations at the source of the upper Blue Nile. Remote Sens. 2014, 6, 6688-6708. [CrossRef]

60. Piani, C.; Weedon, G.; Best, M.; Gomes, S.; Viterbo, P.; Hagemann, S.; Haerter, J. Statistical bias correction of global simulated daily precipitation and temperature for the application of hydrological models. J. Hydrol. 2010, 395, 199-215. [CrossRef]

61. Gissila, T.; Black, E.; Grimes, D.; Slingo, J. Seasonal forecasting of the Ethiopian summer rains. Int. J. Climatol. 2004, 24, 1345-1358. [CrossRef]

62. Kang, Y.; Khan, S.; Ma, X. Climate change impacts on crop yield, crop water productivity and food security-A review. Prog. Nat. Sci. 2009, 19, 1665-1674. [CrossRef]

63. Thompson, J.; Green, A.; Kingston, D.; Gosling, S. Assessment of uncertainty in river flow projections for the Mekong River using multiple GCMs and hydrological models. J. Hydrol. 2013, 486, 1-30. [CrossRef]

64. Chen, J.; Brissette, F.P.; Poulin, A.; Leconte, R. Overall uncertainty study of the hydrological impacts of climate change for a Canadian watershed. Water Resour. Res. 2011, 47. [CrossRef]

65. Zhang, X.; Xu, Y.-P.; Fu, G. Uncertainties in SWAT extreme flow simulation under climate change. J. Hydrol. 2014, 515, 205-222. [CrossRef]

66. Wood, A.W.; Leung, L.R.; Sridhar, V.; Lettenmaier, D. Hydrologic implications of dynamical and statistical approaches to downscaling climate model outputs. Clim. Chang. 2004, 62, 189-216. [CrossRef] 
67. Qiao, L.; Zou, C.B.; Gaitán, C.F.; Hong, Y.; McPherson, R.A. Analysis of precipitation projections over the climate gradient of the Arkansas Red River basin. J. Appl. Meteorol. Climatol. 2017, 56, 1325-1336. [CrossRef]

68. Brigode, P.; Oudin, L.; Perrin, C. Hydrological model parameter instability: A source of additional uncertainty in estimating the hydrological impacts of climate change? J. Hydrol. 2013, 476, 410-425. [CrossRef] 